УДК 346.9: 347.725

DOI https://doi.org/10.32849/2663-5313/2020.9.14

\author{
Анастасія Прокопюк, \\ аспірантка \\ Інституту права \\ Київського начіонального університету імені Тараса Шевченка, \\ помічник суддi \\ Господарського суду міста Києва
}

\title{
ПОНЯТТЯ ТА ОЗНАКИ КОРПОРАТИВНОЇ ВІДПОВІДАЛЬНОСТІ
}

Корпоративна відповідальність є важливим інструментом захисту прав та законних інтересів учасників корпоративних відносин, кредиторів та інших стейкхолдерів. У вітчизняній юридичній літературі відсутні фундаментальні дослідження корпоративної відповідальності. Норми, що визначають корпоративну відповідальність, не систематизовані і містяться в різногалузевих законодавчих правових нормах, локальних правових актах та корпоративних договорах.

Розвиток інституту корпоративної відповідальності зумовлений розвитком корпоративних організаційно-правових форм, удосконаленням корпоративного законодавства та законодавства про неплатоспроможність, впровадженням інституту похідного позову, становленням судової практики притягнення до відповідальності акціонерів та посадових осіб за різного роду зловживання в проиесі реалізації корпоративних прав та управління акиіонерними товариствами, впровадженням доктрини «проникнення за корпоративну вуаль».

Відповідальність у корпоративному праві є різновидом юридичної відповідальності, що має власні інституиійні ознаки й особливості. До ознак корпоративної відповідальності віднесено: а) юридичну (закон, статут, локальний правовий акт, корпоративний договір) та фактичну (корпоративне правопорушення - порушення корпоративних прав інших учасників або фідуціарних обов'язків посадових осіб) підстави виникнення; б) зміст - позбавлення (обмеження) певного корпоративного права або покладення на правопорушника додаткового обов'язку, в) суб'єктний склад - учасники корпоративних відносин, г) застосування у встановленому процесуальному (прочедурному) порядку, г) забезпечення виконання обов'язків учасників корпоративних правовідносин; д) приниип обмеженої відповідальності акиіонерів, які несуть відповідальність за зобов'язаннями товариства лише у випадках, прямо передбачених законом або корпоративним договором; е) приниип окремої майнової відповідальності корпорачії, ї учасників, посадових осіб та пов'язаних осіб (кіниевих бенефічіарів, тіньових директорів); є) мета - покарання порушника та забезпечення захисту прав учасників корпоративних відносин, кредиторів та інших стейкхолдерів.

Системний взаємозв'язок норм, що передбачають корпоративну відповідальність, дозволяє визнати їі інститутом корпоративного права.

Ключові слова: корпоративна відповідальність, корпоративні відносини, корпоративні спори.

Постановка проблеми. Корпоративна відповідальність є одним 3 найважливіших факторів, що забезпечують стабільність розвитку корпоративних правовідносин. Це зумовлює науковий інтерес до корпоративної відповідальності протягом всієї історії розвитку корпоративного права, зумовлений розвитком організаційно-правових форм здійснення господарської діяльності, заснованих на корпоративних відносинах.

Ще в XIX столітті вченими одним 3 інститутів акціонерного права виділявся інститут відповідальності [1, с. 536]. Корпоративна відповідальність $є$ інструментом захисту майнових інтересів акціонерів, товариства, кредиторів, інших стейкхолдерів від порушень, що є наслідком як зловживань, так і відсутності чітко визначеної компетенції кожного органу компанії, а також компенсувати ризики, що виникають у зв'язку 3 використанням правової форми господарського товариства.

Попри прийняття Законів України від 17 вересня 2008 року № 514-VI «Про акціонерні товариства» [2], від 6 лютого 2018 року № 2275-VIII «Про товариства 3 обмеженою та додатковою відповідальністю»[3] та постійну роботу з удосконалення корпоративного законодавства, інститут корпоративної відповідальності не отримав на цьому етапі належного правового регулювання. Зазвичай проблема відповідальності має другорядний характер порівняно з іншими питаннями, пов'язаними з правовим регулю- 
ванням діяльності акціонерних товариств, зокрема, порядком створення і припинення, корпоративними правами та корпоративним управлінням. Як наслідок, учасники корпоративних відносин досить рідко несуть юридичну відповідальність.

Класичний підхід до обмеженості відповідальності учасників (акціонерів) за боргами акціонерного товариства розміром їх частки в статутному капіталі змінився внаслідок прийняття таких нормативно-правових актів: Закони України від 7.04.2015 року № 289-VIII «Про внесення змін до деяких законодавчих актів України щодо захисту прав інвесторів» [4], «Про внесення змін до деяких законодавчих актів України щодо визначення кінцевих вигодоодержувачів юридичних осіб та публічних діячів» [5] від 14.10.2014 р № 1701-VII, «Про внесення змін до деяких законодавчих актів України щодо вдосконалення системи гарантування вкладів фізичних осіб та виведення неплатоспроможних банків з ринку» від 16.07.2015 р. № 629-VIII [6]; Кодекс України з процедур банкрутства [7].

Значний вплив на розвиток корпоративних відносин має судова практика Верховного Суду. Впровадження інституту похідного позову, збільшення кількості спорів щодо притягнення до відповідальності членів органів управління господарських товариств свідчить про потребу в розвитку та застосуванні інституту корпоративної відповідальності. Все це вимагає проведення дослідження інституту корпоративної відповідальності.

Аналіз останніх досліджень і публікацій. Останніми роками дослідження питань відповідальності осіб, що здійснюють управління акціонерним товариством, набуло особливої актуальності. Проблематику відповідальності учасників корпоративних відносин досліджували в своїх працях Б. Блек, A.В. Габов, О.М. Вінник, I.I. Гришина, В.В. Долинська, О.Р. Кібенко, В.М. Кравчук, Д.В. Ломакін, І.В. Лукач, Ю.М. Жорнокуй, P.А. Майданик, В.М. Махінчук, О.Є. Молотніков, Ю.Ю. Симонян, І. В. Спасибо-Фатєєва, С.О. Чеховська, Б.В. Шуба та інші. Окремі аспекти корпоративної відповідальності як способу покладення відповідальності на осіб, які контролюють процес корпоративного управління в АТ, активно досліджується останніми роками в межах доктрини «проникнення за корпоративну вуаль», зокрема такими вченими, як Ю.М. Жорнокуй, B.М. Махінчук, І.В. Спасибо-Фатєєва та інші. Цивільно-правова відповідальність по відшкодуванню збитків, заподіяних недобросовісними засновниками, на думку I.В. Спа-
сибо-Фатєєвої, є найбільш адекватною і саме до неї слід надати можливість суддям притягати порушників за допомогою доктрини «зняття корпоративної вуалі» [8, с. 17-18].

Метою статті є дослідження корпоративної відповідальності як виду юридичної відповідальності, визначення іiї ознак та принципів.

Виклад основного матеріалу. В юридичній літературі переважає плюралізм поглядів на питання визнання відповідальності в корпоративному праві самостійним видом юридичної відповідальності [9, с. 21]. Корпоративна відповідальність характеризується тими ж загальними ознаками, що і юридична відповідальність загалом. Водночас підставою виділення корпоративної відповідальності як окремого виду є сукупність притаманних їй інституційних ознак, що зумовлені правовою природою корпоративних відносин, до яких слід віднести:

1) є самостійним видом юридичної відповідальності. На думку О.В. Гутнікова, корпоративна відповідальність за критеріями презумпції невинуватості порушника, характеру порушення і наявності (відсутності) правового зв'язку між порушником і потерпілим займає особливе місце і може бути виділена в самостійний вид цивільно-правової відповідальності [10, с. 10]. Водночас виокремлення корпоративної відповідальності як самостійного виду відповідальності зумовлює практичну проблему визначення співвідношення норм про відповідальність, передбачених корпоративним законодавством, та загальних норм про цивільно-правову договірну та деліктну відповідальність.

На нашу думку, потрібно визнати існування окремого виду відповідальності - корпоративної відповідальності та спеціальний характер норм корпоративного законодавства, що має наслідком неможливість застосування до цих правовідносин загальних норм про деліктну та договірну відповідальність. Одночасне застосування як норм корпоративної відповідальності, так і загальних норм про договірну та деліктну відповідальність суперечить принципам корпоративної відповідальності.

Яскравим прикладом такого змішування є задоволення позову про стягнення збитків за нормами деліктного права, які передбачають відшкодування будь-якої шкоди, у справі, коли стягнути збитки за нормами корпоративного права неможливо, наприклад, коли контролюючий акціонер або посадова особа діяли розумно та добросовісно, в межах звичайного підприємницького ризику 3 дотриманням правила «ділового рішення». 
Актуальним є співвідношення норм про відповідальність посадових осіб у разі банкрутства і норм деліктної відповідальності за шкоду, заподіяну посадовими особами майновим правам кредиторів. Сама можливість притягнення контролюючих осіб до відповідальності після завершення процедури банкрутства за цивільно-правовими нормами про делікт обгрунтовано викликає сумніви у О.В. Гутнікова, оскільки в цьому разі стягнення здійснюється в обхід конкурсної маси і стягувач отримує невиправдані переваги перед іншими кредиторами, які втратили можливість отримати задоволення своїх вимог в процедурі банкрутства [10, с. 15]. Сам факт включення відповідних норм у законодавство про неспроможність дає підстави трактувати таку відповідальність як особливу відповідальність осіб, що здійснюють управління товариством у разі банкрутства, що відрізняється від відповідальності, передбаченої корпоративним законодавством.

У зв'язку з цим і законодавство, і судова практика пішли шляхом розширення підстав притягнення до відповідальності контролюючих осіб у разі банкрутства порівняно з підставами, передбаченими корпоративним законодавством. У разі банкрутства контролюючі особи можуть бути притягнуті до відповідальності вже за сам факт контролю на підставі презумпції вини, що, по суті, веде до розмивання меж юридичної особи та порушення принципу відокремлення відповідальності товариства та акціонерів.

На думку О.В. Гутнікова, відповідальність контролюючих осіб у разі банкрутства - це різновид корпоративної відповідальності на стадії припинення юридичної особи в умовах недостатності її майна. Вона виникає у відносних корпоративних відносинах, пов'язаних з управлінням юридичною особою на стадії її припинення, і повинна підкорятися загальним правилам корпоративної відповідальності, передбаченим корпоративним законодавством [10, с. 16-17]. Порушення, за які посадові особи несуть відповідальність у разі банкрутства, пов'язані 3 порушеннями під час здійснення управлінських повноважень.

Притягнення контролюючих боржника осіб до субсидіарної відповідальності $є$ виключним механізмом відновлення порушених прав кредиторів. У разі його застосування судам необхідно враховувати як сутність конструкції юридичної особи, яка передбачає майнову відокремленість цього суб'єкта, його самостійну відповідальність, наявність в учасників корпорації, засновників унітарних організацій, інших осіб, що входять до складу органів юридичної особи, свободи розсуду під час прийняття (узгодження) ділових рішень, так і заборону на заподіяння ними шкоди учасникам обороту за допомогою недобросовісного використання інституту юридичної особи;

2) юридичною підставою корпоративної відповідальності є закон, статут, локальний правовий акт, корпоративний договір.

Нормативною підставою виокремлення корпоративної відповідальності є виокремлення корпоративних відносин як особливого виду господарсько-правових відносин.

Корпоративна відповідальність встановлюється нормами різних галузей права. Складність і багатогранність корпоративних правовідносин призвели не тільки до теоретичних спорів про їх природу, а й до врегулювання діяльності їх учасників нормами різних галузей права. Наприклад, відносини акціонерного товариства і особи, яка здійснює функції одноосібного виконавчого органу, членів колегіального виконавчого органу, є предметом регулювання не тільки ЦК України [11] та Закону «Про акціонерні товариства», а й Кодексу законів про працю [12], Кримінального кодексу України [13].

За одне і те саме правопорушення, що тягне за собою корпоративну відповідальність, особа може бути притягнута до відповідальності, передбаченої іншими галузями права (за окремими винятками, що випливають із специфіки правового статусу учасників корпоративних правовідносин). Це зумовлено в тому числі тією обставиною, що відповідальність відповідно до норм публічного права не виключає застосування за одне і те саме порушення цивільно-правової (майнової) відповідальності, оскільки остання виконуе правовідновлюючу функцію, а перша має характер покарання [14, с. 171].

У зв'язку з особливостями правового статусу окремих учасників корпоративних відносин до них не можуть бути застосовані санкції всіх галузей права. Найбільш яскравим прикладом є кримінально-правова відповідальність. У Франції ордонанс 1670 р. вже передбачав відповідальність за злочини, які здійснювалися товариствами та корпораціями. Чинний Кримінальний кодекс Франції (1992) визначає, що кримінальну відповідальність несуть всі юридичні особи, крім держави. Федеральне кримінальне законодавство і законодавство окремих штатів США також визнають інститут відповідальності корпорацій і визначають, що корпорації за певних обставин можуть нести кримінальну відповідальність поряд з фізичними особами чи самостійно [15, с. 26-27]. Повноцінне визнання інститут кримінальної відповідальності юридичних осіб у європей- 
ських країнах (Австрії, Угорщині, Бельгії, Данії, Нідерландах, Норвегії, Іспанії, Швейцарії, Фінляндії) отримав лише в 90 -х роках $\mathrm{XX}$ ст. Результатом прийняття спеціальних законів про кримінальну корпоративну відповідальність за злочини, вчинені від імені компанії або тісно пов'язані з її діяльністю, стало підвищення рівня свідомості компаній у веденні бізнесу.

Відповідно до Закону Бельгії від 4.05.1999 року (Law on the criminal liability of legal entities) юридична особа не може нести відповідальність за злочин, що може бути скоєний лише фізичною особою, та звільняється від відповідальності, якщо злочин вчинено працівником, який діяв поза межами посадової інструкції. Покаранням за вчинений злочин для юридичної особи є: штрафи; конфіскація дво- або трикратного розміру прибутку, отриманого у результаті маніпулювання на ринку, інсайдерської торгівлі; конфіскація активів; заборона займатись певними видами діяльності; примусова реорганізація або ліквідація.

В Україні до 2014 року до кримінальної відповідальності могла бути притягнена лише фізична особа. Зміни до Кримінального та Кримінально-процесуальних кодексів України внесені Законом України від 23 травня 2013 року № 314-VII «Про внесення змін до деяких законодавчих актів України щодо виконання Плану дій щодо лібералізації Європейським Союзом візового режиму для України стосовно відповідальності юридичних осіб» [16].

Вчені наголошують на неузгодженості можливості притягнення юридичної особи до кримінальної відповідальності із принципом особистої відповідальності, а також суб'єктивної осудності. Адже юридична особа сама не вчиняе протиправних дій; дії вчиняються фізичними особами, і лише фізичні особи можуть усвідомлювати суспільну небезпечність дій (бездіяльності). Тому законодавець не включив юридичних осіб до суб'єктів злочину, якими залишаються виключно фізичні особи. До норм загальної частини Кримінального кодексу України додано розділ XIV-1 «Заходи кримінально-правового характеру щодо юридичних осіб».

У випадках вчинення уповноваженою особою юридичної особи або за дорученням чи наказом, за змовою та в співучасті, або іншим шляхом від імені та в інтересах юридичної особи будь-якого із злочинів, передбачених ч. 1 ст. 963 КК України, до юридичних осіб можуть бути застосовані такі заходи кримінально-правового характеру, як штраф, конфіскація майна та ліквідація.
Фактичною підставою корпоративної відповідальності є вчинення корпоративного правопорушення. Корпоративна відповідальність настає за порушення корпоративних прав інших учасників корпоративних відносин та фідуціарних обов'язків посадових осіб, встановлених нормами корпоративного права, особою, яка перебуває з корпорацією у відносних корпоративних відносинах. При цьому шкода, що виникає в результаті порушення корпоративних обов'язків, пов'язаних з управлінням юридичною особою, може бути заподіяна як іншим учасникам корпоративних відносин, які також перебувають з порушником у відносних корпоративних відносинах, так і третім особам, які в таких відносинах із заподіювачем шкоди не перебувають;

3) зміст. Корпоративна відповідальність полягає в позбавленні (обмеженні) певного корпоративного права або покладенні на правопорушника додаткового обов'язку. Корпоративна відповідальність має особливі форми (санкції): обмеження корпоративних прав (права голосу, права на отримання дивідендів), виключення учасника зі складу корпорації (примусове припинення права участі в корпорації), визнання недійсним засновницького договору або статуту, примусовий поділ або ліквідація товариства, спрямовані як на майнову базу, так і на особу порушника. Така ознака відповідае загальному підходу до розуміння відповідальності як санкції за правопорушення, що викликає для порушника будь-які негативні наслідки у вигляді позбавлення суб'єктивних цивільних прав або покладання нових або додаткових цивільно-правових обов'язків [17, с. 97] та зумовлюе право потерпілої особи на поновлення порушеного права і компенсацію завданої шкоди, забезпечених можливістю застосування державного примусу [18, с. 269].

4) суб'єктами корпоративної відповідальності є учасники корпоративних відносин. B.М. Кравчук визначає корпоративні відносини як відносини між учасником і товариством щодо участі у товаристві [19, с. 10].

О.В. Кологойда до суб'єктів корпоративної відповідальності, крім самого товариства, його учасників (акціонерів) та посадових осіб органів управління, відносить: а) засновників товариства; б) інших осіб, які мають право давати обов'язкові для товариства (боржника) вказівки чи мають можливість іншим чином визначати його дії (наприклад, голова та члени комісії 3 припинення АТ, арбітражний керуючий (розпорядник майна, керуючий санацією, ліквідатор), особи, що входять до нелегі- 
тимних органів управління, «колишні» члени органів управління, «тіньові» директори); в) осіб, які несуть субсидіарну відповідальність за зобов'язаннями боржника за законом; г) кінцевих бенефіціарних власників (контролерів) господарського товариства; г) пов'язаних з банком осіб [20, с. 10];

5) корпоративна відповідальність може бути застосована лише у встановленому в нормах корпоративних або загальних правових актів процесуальному (процедурному) порядку. Притягнення до корпоративної відповідальності пов'язане із застосуванням корпоративного примусу [21, с. 317];

6) забезпечує виконання обов'язків учасників корпоративних правовідносин, стимулюючи діяти добросовісно, розумно та в інтересах товариства;

7) має обмежений характер. Діяльність акціонерних товариств базується на принципі особливого режиму відповідальності їх учасників - принципі обмеженої відповідальності акціонерів (ч. 2 ст. 3 Закону «Про акціонерні товариства»).

Принцип обмеженої відповідальності учасників акціонерних товариств історично став визначальною передумовою виокремлення організаційно-правової форми акціонерного товариства. Саме тому, що засновники та акціонери не відповідали за боргами акціонерного товариства, i розпочався бурхливий ріст світової економіки, відбулось становлення індустріальної економіки [22, с. 451]. Об'єднання капіталів дозволило акумулювати величезні кошти, які можна порівняти за розміром з бюджетами середніх європейських держав. Акціонерні компанії були в змозі реалізувати практично будь-які проєкти: будівництво залізниць або освоєння нових територій на іншому кінці земної кулі. Однак поряд 3 неймовірним позитивним ефектом акціонерні товариства започаткували практику небачених за своїми масштабами зловживань і розорення величезної кількості людей (акціонерів) [9, с. 20]. Спочатку основним способом введення в оману недосвідчених акціонерів було створення «дутих» компаній, які найчастіше ставили за мету свідомо недосяжні цілі (наприклад, у Голландії в розпал акціонерної гарячки XVII ст. у проспектах акціонерних компаній зустрічались згадки про perpetuum mobile, добування дубового масла тощо [1, с. 86]). Велика кількість зловживань була пов'язана 3 діяльністю засновників, що були посадовими особами цих компаній.

Після численних банкрутств, що супроводжувалися скандалами і хвилюваннями серед рядових акціонерів, які в одну мить втрачали величезну купу грошей, європей- ські держави посилили процедуру контролю за створенням компаній і перейнялися проблемою відповідальності засновників акціонерних компаній (Bubble act (1720 г.) в Англії, закон 26 Жерміналь II року республіки у Франції (1794 г.) тощо), що зменшило кількість і масштаби порушень та зняло соціальну напругу серед акціонерів.

У ХХ ст. простежується тенденція відсторонення акціонерів від управління поточною діяльністю компанії. Все частіше акціонерними товариствами стали управляти професійні менеджери, які не володіли акціями очолюваних ними компаній. Це призводило до внутрішніх конфліктів між учасниками корпоративних відносин, а також до зловживань з боку найманих менеджерів компанії. Зазначені обставини підштовхнули до подальшого розвитку інституту відповідальності. Однак, на відміну від попередніх етапів, акцент був зроблений на відповідальності осіб, що входять до складу органів управління компанії, а отже, мають можливість розпоряджатися майном компанії. Детальна регламентація діяльності менеджерів знайшла втілення у правовій системі США, звідки була запозичена й іншими країнами світу [23], однак гучні акціонерні скандали (наприклад, Enron) засвідчили, що вказана система регулювання також не є досконалою.

За загальним правилом, відповідальність перед кредиторами несе лише саме товариство як юридична особа. Відповідно до ч. 1 ст. 96 ЦК України [11] юридична особа самостійно відповідає за своїми зобов'язаннями. Саме деліктоздатність дозволяє корпораціям бути повноправними суб'єктами права і дає можливість вступати з іншими суб'єктами у правовідносини.

Учасник (засновник) юридичної особи не відповідає за зобов'язаннями юридичної особи, а юридична особа не відповідає за зобов'язаннями ii учасника (засновника), крім випадків, встановлених установчими документами та законом (ч. 3 ст. 96 ЦК України). На цьому принципі, як зазначає Ю.М. Жорнокуй, грунтується й обмеження відповідальності акціонерів товариства за його боргами їх вкладами до його майна, що складає сутність самої конструкції юридичної особи як корпоративного «щита», який захищає особисте майно іï учасників від вимог третіх осіб (кредиторів товариства) [24, с. 338]. Акціонер приймає на себе підприємницький ризик, межі якого обмежуються сумами, внесеними в оплату за акції. Акціонери не відповідають за зобов'язаннями товариства і несуть ризик збитків, пов'язаних з діяльністю товариства, в межах належних імм акцій. Акціонери можуть нести відпо- 
відальність за зобов'язаннями товариства лише у випадках, прямо передбачених законом або корпоративним договором;

8) заснована на принципі окремої майнової відповідальності корпорації, її учасників (засновників, акціонерів, членів), посадових осіб та членів органів управління, інших осіб (пов'язаних осіб, кінцевих бенефіціарних власників). Є.А. Суханов зазначає, що зазначений принцип зумовлений принципом відокремлення особи та майна компанії від особи та майна її учасників та вигодонабувачів [25, с. 15].

Важливим напрямом розвитку корпоративного законодавства має стати розробка механізму, який перешкоджає використанню організаційно-правової форми господарського товариства як фасаду (щита), що приховує недобросовісні дії і протиправні інтереси учасників товариства та осіб, що здійснюють функції органів управління і здатні визначати діяльність товариства. В результаті порушуються права та охоронювані законом інтереси як самого товариства, так і його кредиторів. Передумови виникнення такої ситуації полягають у конструкції господарського товариства, яке заміщає в цивільному обороті своїх учасників. Учасники, об'єднавшись у корпоративну організацію, вже не реалізують свої приватні інтереси, а отримують задоволення своїх потреб через здійснення загального корпоративного інтересу в процесі діяльності товариства [26, с. 42]. Всі вони мають потенційну можливість використовувати свої повноваження всупереч інтересам товариства.

Необхідно розмежувати відповідальність учасників корпоративних відносин і відповідальність товариства як юридичної особи поза зв'язком 3 цим видом правовідносин. Другий вид відповідальності не є корпоративною;

9) мета, яка полягає не тільки в покаранні винного, але і в забезпеченні захисту прав учасників корпоративних відносин, кредиторів та інших стейкхолдерів.

\section{Висновки}

Таким чином, корпоративна відповідальність є самостійним видом юридичної відповідальності, що має свої інституційні ознаки та особливості. Хоча норми про корпоративну відповідальність мають несистемний характер і складаються з сукупності норм, закріплених в різних нормативно-правових актах, вони мають єдиний предмет правового регулювання - корпоративні відносини, що дозволяє визнати корпоративну відповідальність інститутом корпоративного права, а не простою сукупністю правових норм.

\section{Список використаних джерел:}

1. Тарасов И.Т. Учение об акционерных компаниях. Москва, 2000. 665 с

2. Про акціонерні товариства: Закон України від 17 вересня 2008 р. № 514-VI. URL: https://zakon.rada.gov.ua/laws/show/514-17\#Text (дата звернення: 05.09.2020).

3. Про товариства 3 обмеженою та додатковою відповідальністю від 6 лютого 2018 року № 2275-VIII. URL: https://zakon.rada. gov.ua/laws/ show/2275-19\#Text (дата звернення: 05.09.2020).

4. Про внесення змін до деяких законодавчих актів України щодо захисту прав інвесторів: Закон Україні від 7.04.2015 р. № 289-VIII. URL: https://zakon.rada.gov.ua/laws/show/289-19\#Text (дата звернення: 05.09.2020).

5. Про внесення змін до деяких законодавчих актів України щодо визначення кінцевих вигодоодержувачів юридичних осіб та публічних діячів: Закон України від 14.10.2014 р. № 1701-VII. URL: https://zakon.rada.gov.ua/laws/ show/1701-18\#Text (дата звернення: 05.09.2020).

6. Про внесення змін до деяких законодавчих актів України щодо вдосконалення системи гарантування вкладів фізичних осіб та виведення неплатоспроможних банків з ринку: Закон України № 629-VIII від 16.07.2015 p. URL: https://zakon.rada.gov.ua/laws/show/629-19\#Text (дата звернення: 05.09.2020).

7. Кодекс України з процедур банкрутства. URL: https://zakon.rada.gov.ua/laws/show/2597-19\# Text (дата звернення: 05.09.2020).

8. Спасибо-Фатєєва I. В. Доктринальне тлумачення. Вісник Академії правових наук України. 2005. № 1. C. 14-24.

9. Молотников А.Е. Ответственность в акционерных обществах. Москва : Волтерс Клувер, 2006. $240 \mathrm{c}$.

10. Гутников О.В. Основания разработки категории корпоративной ответственности в гражданском праве. Право. Журнал Высшей школы экономики. 2019. № 4. С. 4-30.

11. Цивільний кодекс України від 16 січня 2003 p. № 435-IV. URL: https://zakon.rada.gov.ua/ laws/show/435-15\#Text (дата звернення: 05.09.2020).

12. Кодекс законів про працю URL: https://zakon.rada.gov.ua/laws/show/322-08\#Text (дата звернення: 05.09.2020).

13. Кримінальний кодекс України URL https://zakon.rada.gov.ua/laws/show/2341-14\#Text.

14. Захаров В.А. Создание юридических лиц: Правовые вопросы. Москва : НОРМА, 2002. 208 с.

15. Иванов А.А., Керимов М.К. О юридических лицах как субъектах юридической ответственности. Закон и право. Вип. 10. 2008. С. 26-27.

16. Про внесення змін до деяких законодавчих актів України щодо виконання Плану дій щодо лібералізації Європейським Союзом візового режиму для України стосовно відповідальності 
юридичних осіб: Закон України від 23 травня 2013 року № 314-VII. URL: https://zakon.rada. gov.ua/laws/show/314-18\#Text (дата звернення: 05.09.2020).

17. Иоффе О.С. Обязательственное право. Москва, 1975. 880 c.

18. Шуба Б.В. Відповідальність учасників господарського товариства як засіб захисту інтересів його кредиторів (порівняльно-правовий аналіз німецького і українського права) : автореф. дис. ... канд. юрид. наук : 12.00.03. Харків, 2005. 20 с.

19. Кравчук В.М. Припинення корпоративних правовідносин в господарських товариствах : автореферат дис. ... докт. юр. наук : 12.00 .03 / В. М. Кравчук. Харків, 2010. 34 с.

20. Кологойда О.В. Суб'єкти корпоративної відповідальності у формі відшкодування збитків. Журнал східноєвропейського права. 2016. № 31. C. 4-14.
21. Кравчук В. М. Корпоративне право: науково-практичний коментар законодавства та судової практики. Київ : Істина, 2005. 720 с.

22. Корпоративное право / Под ред. И.С. Шиткиной. Москва, 2008. 648 с.

23. Сыродоева О.Н. Акционерное право США и России: сравнительный анализ. Москва : СПАРК, 1996. $112 \mathrm{c}$.

24. Жорнокуй Ю.М. Цивільно-правова природа корпоративних конфліктів в акціонерних товариствах: дис. ... д-ра юрид. наук : 12.00.03 / Жорнокуй Юрій Михайлович ; Нац. юрид. ун-т ім. Ярослава Мудрого. Харків, 2016.

25. Суханов Е.А. Сравнительное корпоративное право. Москва : Статут, 2014. 456 с.

26. Ломакин Д.И. Основные тенденции развития современного законодательства о хозяйственных обществах. Вестник Московского университета. Серия 11 Право. 2010. № 5. С. 27-45.

\section{Anastasia Prokopyuk. Corporate responsibility's concept and features}

Corporate responsibility is an important tool of the corporate parties, creditors and other stakeholders' rights and legitimate interests protection. There are no fundamental studies of corporate responsibility in the domestic legal literature. Corporate responsibility norms are not systematized and are contained in various legal norms, local legal acts and corporate agreements.

The corporate responsibility institute development is due to the corporate legal forms development, improvement of corporate and insolvency law, the introduction of the derivative lawsuits institute, shareholders and boards prosecuting judicial practice for various abuses of corporate rights and corporate governance, the doctrine of "piercing the corporate veil" implementation.

The corporate law liability is atype of legalliability that hasitsown institutional features and characteristics. The signs of corporate responsibility include: a) legal (law, charter, local legal act, corporate agreement) and factual (corporate offense - violation of the corporate participants corporate rights or the officials fiduciary duties) grounds, b) content - the offender deprivation (restrictions) of a certain corporate rights or the additional obligation imposing on; c) subjects - the corporate relations participants, $d$ ) application in accordance with the established procedural procedure; $e$ ) ensuring the fulfillment of the corporate legal relations participants obligations; $e$ ) the principle of the shareholders limited liability who are liable for the company obligations only in the cases expressly provided by law or the corporate agreement; f) the principle of separate property liability of the corporation, its members, officials and related parties (beneficiaries, shadow directors); $g$ ) purpose - to punish the violator and to ensure the corporate relations participants, creditors and other stakeholders rights protection.

System interconnection standards that provide corporate responsibility, allowes to recognize it as a corporate institution.

Key words: corporate responsibility, corporate relations, corporate disputes. 